\title{
Doctoral Student Learning Patterns: Learning about Active Knowledge Creation or Passive Production
}

\author{
Jenna Vekkaila ${ }^{1} \&$ Kirsi Pyhältöo ${ }^{2,3}$ \\ ${ }^{1}$ Faculty of Theology, University of Helsinki, Helsinki, Finland \\ ${ }^{2}$ Faculty of Educational Sciences, University of Oulu, Oulu, Finland \\ ${ }^{3}$ Center for Research and Development of Higher Education, University of Helsinki, Helsinki, Finland \\ Correspondence: Jenna Vekkaila, Faculty of Theology, P.O. Box 4, 00014 University of Helsinki, Finland. Tel: \\ $358-44-5692632$.
}

Received: March 18, 2016

Accepted: April 9, 2016

Online Published: April 15, 2016

doi:10.5430/ijhe.v5n2p222

URL: http://dx.doi.org/10.5430/ijhe.v5n2p222

\begin{abstract}
Doctoral studies are about learning to create new knowledge and to become a researcher. Yet surprisingly little is known about the individual learning patterns of doctoral students. The study aims to explore learning patterns among natural science doctoral students. The participants included 19 doctoral students from a top-level natural science research community. The data were collected through interviews and qualitatively content analysed. Five qualitatively different learning patterns were identified: 1) active knowledge creator, 2) active producer, 3) active project manager, 4) passive producer and 5) conformist. The patterns differed from each other in how the participants approached their learning regarding conducting research and becoming a researcher, learning strategies and their perceptions of learning objects. This indicates that learning environments need to be adjustable to different doctoral student learning patterns. At best, by designing practices in congruence with doctoral students' ways of learning, scholarly communities can provide flourishing environments in which doctoral students are able to become autonomous scientists who conduct high quality research. To our knowledge, doctoral students' learning patterns have not been previously reported in doctoral education literature. This study contributed to the literature on doctoral student learning and provided new insight into the complexity of learning processes among natural science doctoral students by identifying five qualitative different learning patterns.
\end{abstract}

Keywords: Doctoral student, Qualitative research, Learning pattern, Natural science, Postgraduate education

\section{Introduction}

Learning is at the core of doctoral studies (Brew, Boud, \& Namgung, 2011; Pyhältö, Nummenmaa, Soini, Stubb, \& Lonka, 2012). Doctoral studies entail learning about research and making an original contribution to knowledge (Delamont \& Atkinson, 2001; Lovitts, 2005; Saunders, 2009). They are also about learning to become a researcher (McAlpine \& Amundsen, 2009; McAlpine, Jazvac-Martek, \& Hopwood, 2009; Pyhältö et al., 2012; Sweitzer, 2009) and to engage in a scholarly community (Austin, 2002; Gardner, 2007; McAlpine \& Norton, 2006; Pyhältö, Stubb, \& Lonka, 2009; White \& Nonnamaker, 2008). Doctoral journeys are suggested to vary in terms of their unique individual characteristics (McAlpine et al., 2009; Lovitts, 2001; Vekkaila, Pyhältö, \& Lonka, 2013a, b). Lahenius and Martinsuo (2011), for instance, identified three different types of doctoral journeys among doctoral students in industrial engineering and management: the students' orientations towards their doctoral studies differed in their goals, resources and level of progress. Moreover, Terrell (2002) found that doctoral students majoring in educational technology typically employed two learning styles in a web-based learning environment: the converger and the assimilative, which both entailed a high level of abstract conceptualization. The findings, despite of lacking focus on doctoral student learning, imply that doctoral students' learning patterns may differ.

Prior research on higher education student learning has focused heavily on undergraduate students (Vermunt, 2005; Vermunt \& Vermetten, 2004). As a result, we still know surprisingly little on doctoral students' learning. Therefore, a better understanding is needed of doctoral students' learning during their doctoral process. The aim of this study is to explore what learning patterns can be identified among natural science doctoral students. 


\section{Theoretical Framework}

The learning pattern refers to the activities that the student employs in learning, including cognitive strategies, metacognitive regulation, conceptions of learning and approaches to learning (Vermunt, 2005; Vermunt \& Vermetten, 2004). Accordingly, doctoral students' learning patterns encompass activities that they employ in learning to conduct research and to become a researcher. This includes their situated approach to learning and their perceptions of learning objects.

Previous studies on higher education student learning have identified various approaches that undergraduate students apply in learning and studying (Entwistle \& McCune, 2004; Lonka, Olkinuora, \& Mäkinen, 2004). Approaches to learning include learning strategies and the motivation to learn and study (Biggs, 1978; Entwistle \& McCune, 2004). A deep approach to learning that focuses on understanding ideas and the meaning of the learning contents and a surface approach which is characterized by the management of the learning contents and their reproduction have frequently been identified in prior studies on undergraduates (e.g., Lonka et al., 2004). In addition, a strategic approach referring to the organization and monitoring of studying activities has been reported (Entwistle \& McCune, 2004; Entwistle \& Peterson, 2004; Lonka et al., 2004). Yet these studies have focused almost solely on Bachelor's and Master's degree students.

Doctoral students' approaches to learning may also vary. Doctoral students have, for instance, been shown to focus on gaining an in-depth understanding of their research topics (Vekkaila, Pyhältö, Hakkarainen, Keskinen, \& Lonka, 2012; Wisker, Robinson, Trafford, Creighton, \& Warnes, 2003), and frustrating experiences of failing to master certain research areas or techniques have been reported (Delamont \& Atkinson, 2001; Pole, 2000).

The strategies that students apply to learning are the central determinants for successful learning (Lonka et al., 2004; Vermunt, 2005). It has been suggested that the degree to which students are able to regulate their learning i.e., are metacognitively, motivationally, affectively, and behaviourally active participants in their own learning process affects the quality of their learning process and achievements (Pintrich, 2004; Puustinen \& Pulkkinen, 2001; Zimmerman, 2008). Self-regulative learning involves student's goal setting and personal initiatives, selection and development of learning strategies, and self-monitoring of learning activities as well as evaluation of the learning process (e.g., Pintrich, 2004; Puustinen \& Pulkkinen, 2001). For instance, the perceived degree of academic involvement predicts doctoral students' educational outcomes: students that value their involvement more have higher levels of satisfaction with doctoral education and increased perceptions of self-efficacy to conduct scholarly work (Anderson, Cutright, \& Anderson, 2013). Moreover, doctoral students associate active involvement in training with attaining good quality professional development and relationships within scholarly communities (Gardner \& Barnes, 2007). On the other hand, doctoral students who perceive themselves as passive objects within their scholarly community report lower levels of interest towards doctoral studies and have more often considered interrupting their studies than students who are active agents in their communities (Pyhältö \& Keskinen, 2012).

The perceived locus of control may especially contribute to the ways in which students engage in their studies (Vermunt, 2005). For instance, taking the initiative, being self-directed and having an internal locus of control are essential for making the most of doctoral education (Anderson \& Anderson, 2012). In turn, experiences of lacking autonomy and ownership over their doctoral projects are perceived as reasons for students' disengagement from doctoral studies (Vekkaila, Pyhältö, \& Lonka, 2014).

Variations in doctoral students' personal learning objects have been detected (Stubb, Pyhältö, \& Lonka, 2012a). Previous research implies that doctoral students may perceive research primarily as a process of creating new knowledge and developing academic expertise or may focus on the end results, such as acquiring qualifications (Meyer, Shanahan, \& Laugksch, 2005; Stubb, Pyhältö, \& Lonka, 2012b). The way doctoral students perceive their research, in turn, is likely to contribute to how they approach and are involved in their studies (Meyer et al., 2005).

Although previous studies provide some observations on doctoral students' learning, the understanding of doctoral students' learning patterns is still insufficient. The gap in our knowledge exists in particular in understanding what learning patterns are formed by doctoral students' approaches to learning, learning strategies, locus of control and learning objects.

\section{Finnish Doctoral Education in the Natural Sciences}

Finnish natural science doctoral education is based on the European model. Conducting doctoral thesis research is embedded in the activities of the research community. The majority of science students at the University of Helsinki conduct their thesis in the doctoral programme of a research community (Pyhältö, Stubb, \& Tuomainen, 2011).

The requirements for a doctoral degree include 60-80 European Credit Transfer and Accumulation System (ECTS) 
credits worth of postgraduate studies. The course work is usually individually constructed and based on personal study plans, which typically include international conferences and some methodological studies. In addition to the studies, the doctorate involves a dissertation and its public defence. The most frequent type of natural science thesis is a summary of articles (Pyhältö et al., 2011). The articles are often co-authored with the supervisors. Each doctoral student is required to publish from three to five articles in peer-reviewed international journals. In Finland, the language of natural science theses is typically English (Pyhältö et al., 2011).

Natural science doctoral students' funding is often derived from research projects paid for by universities or private foundations (Pyhältö et al., 2011). Natural science doctoral students usually work on their PhDs full time and complete them within approximately four years (Pyhältö et al., 2011). Doctoral education in Finland is described in general by the International Postgraduate Student Mirror (2006) and Pyhältö et al. (2012).

\section{Method}

\subsection{Aim of the Study and Research Question}

The aim of this study is to gain a better understanding of the learning patterns among natural science doctoral students. The following research question was addressed:

What kinds of learning patterns can be identified among natural science doctoral students?

This study is part of a larger research project on doctoral education in Finland (see, for instance, Pyhältö, Stubb \& Lonka, 2009; Pyhältö et al., 2012).

\subsection{Participants}

The participants were 19 natural science doctoral students (women: 10, men: 9; mean age: 27, mode: 25-30 years, varying from twenty to thirty-five years). Most of the participants were Finnish, and all had Master's degrees. Most were pursuing their dissertations full time. They were at different phases of the doctoral process: 11 students were in their first two years of $\mathrm{PhD}$ studies, and 8 were more advanced, having been working on their $\mathrm{PhDs}$ for over two years. The form of their dissertations was a series of articles.

They were from an internationally highly regarded natural science research community of a research-intensive Finnish university. The community was chosen because it represented a research community with structured doctoral education and high academic achievement.

Our study followed the instructions of the research ethics committee in Finland. The research community and the individual participants we informed about the aims and contents of the study both literally in the invitation and face to face at the beginning of the data collection. Each of the participants was asked for their consent individually. Participation in the research was voluntary. The participants were not compensated for their time. They were able to discontinue their participation at any point. Their privacy and confidentiality were protected. All the information on the participants that might have endangered their anonymity was removed from the research data. Only the researcher responsible conducting the interviews i.e., the first author was able connect the data to the participants' personal information. In this paper information on the participants is given as much as possible without compromising their anonymity.

\subsection{Interviews}

Invitation to participate in the study was send to all the doctoral students of the natural science research community. The first author sent an interview invitation to the students by e-mail. The doctoral students contact information was provided by the research community. The invitation included background information on the overall research project and the purpose of the interview.

The doctoral students' learning experiences were explored based on data collected through semi-structured interviews (Kvale, 2007) in the spring of 2009. These interviews provided a flexible structure (Kvale, 2007) for focusing on the doctoral students' perceptions of the key learning experiences of their doctoral journeys. The interviews also included background questions about the time involved in doctoral studies, the type of thesis, the phase of studies and the research focus. The interview questions and instructions were designed by the research group members. The interview protocol was also tested in pilot interviews.

In the interviews each participant was asked to produce a visualization of their doctoral journeys and identify the significant positive and negative experiences of the journeys (Vekkaila et al., 2012, for the critical turning points in learning, see, for instance, Tripp, 1994). Then the visualizations were used to support discussion on the experiences, and each participant in turn was asked to describe their experiences. Specifying questions about the experiences were 
asked when needed (see Appendix).

Each interview lasted from 50 to 150 minutes. The interviews were conducted by the first author, who was also a doctoral student at the time of the interviews. The interviews were recorded, and they were transcribed by a trained research assistant.

\subsection{Analysis}

The doctoral students' learning patterns were qualitatively content analysed (Coffey \& Atkinson, 1996; Haig, 2005). The analysis procedure included three phases.

In the first, data-grounded phase, the interviews were read through several times to obtain an overall understanding. Then all the text segments in which the students referred to learning, meaning changes in their ways of perceiving, thinking and acting in their postgraduate studies, research or thesis or as a student or a researcher were coded into the same hermeneutic category, by using inductive strategy (Harry, Sturges, \& Klingner, 2005; Mills, Bonner, \& Francis, 2006). This resulted in 338 episodes. The unit of analysis included the totality of thought referring to learning, ranging from a sentence to a dozen sentences.

After this, a theory-guided phase (Patton, 1990) followed in which the learning episodes were coded into four basic categories and their subcategories:

(a) Approaches to learning to conduct research and to become a researcher

- Surface: Performance, advancements and the mastering of different tasks related to research and studies

- Deep: Personal thoughts and ideas as well as the deepening of understanding

- Strategic: The organization and progression of the research and studies

(b) Action strategies in the different learning situations

- Adaptive: Conformation to current conditions

- Transformative: The student affects and changes the situations and conditions

(c) Locus of control in the learning process

- External: An outside source controlled the learning

- Internal: The student as the source of control and learning in a personally meaningful manner

(d) Perceptions of learning objects

- Management of products: Learning objects as the management and production of tasks and achievements that followed one another, such as research projects and articles

- The creation of the new: Learning objects as building new knowledge, problem solving as well as the learning and development of academic expertise as a part of a scholarly community

Each participant's text segments as a whole contributed to all of the basic categories. Figure 1 visualizes the basic categories and their subcategories. 


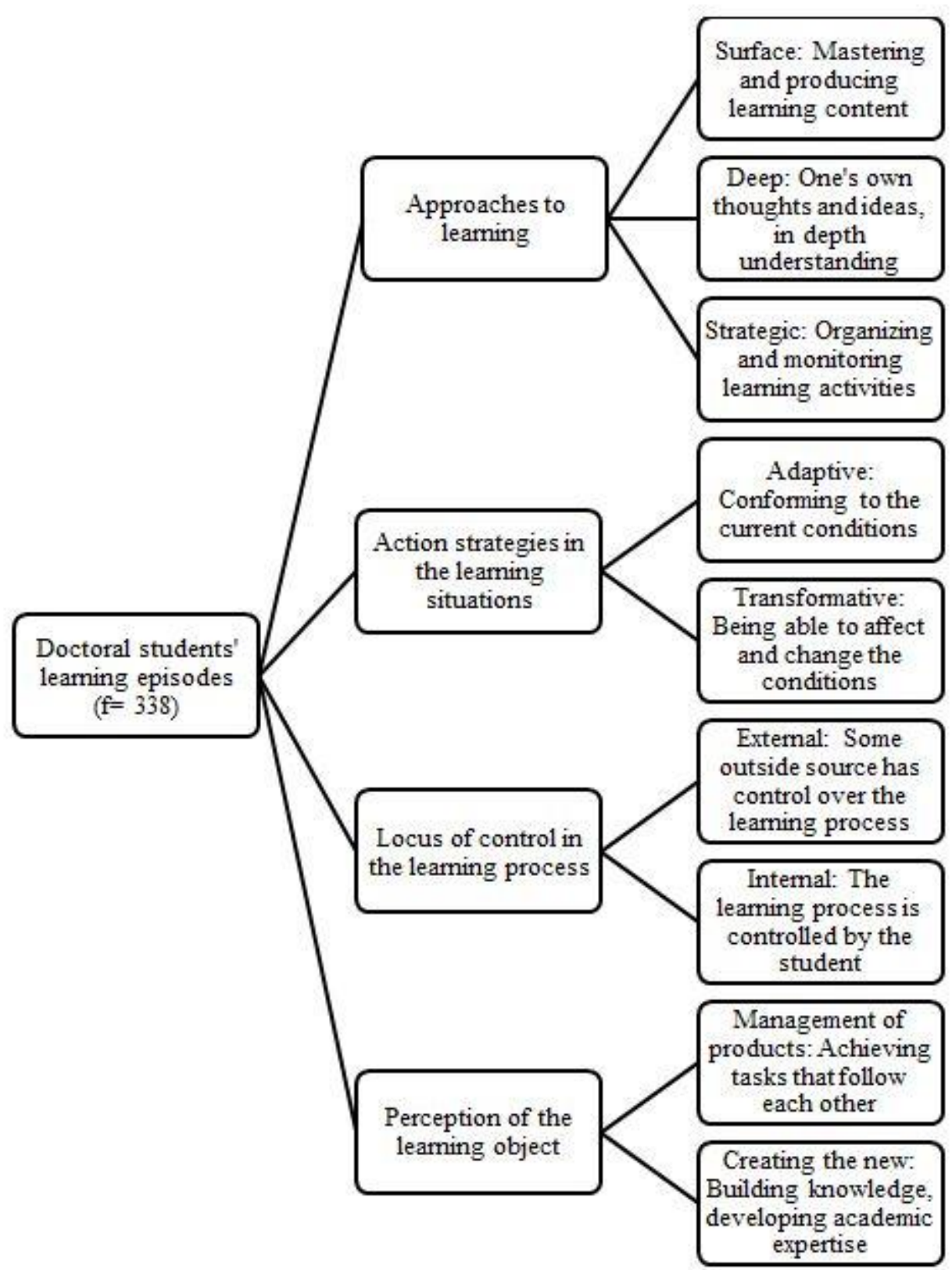

Figure 1. A visualization of the basic categories

Finally, the similarities and differences in the basic categories were explored across all participants. In addition, each participant's learning experiences were interpreted within the larger interview context. Five learning patterns were identified based on the different emphases in the basic categories: 1) active knowledge creator, 2) active producer, 3) active project manager, 4) passive producer and 5) conformist. The patterns differed from each other in how the participants expressed their approaches to learning, their action strategies in the learning situations and their perceptions of the learning object. In all but one pattern the locus of control was considered internal. The characteristics of these patterns are presented in Table 1.

Each phase of the analysis process and the criteria for the categories were discussed and modified in the research group (Miles \& Huberman, 1994). 
Table 1. The doctoral student learning patterns

\begin{tabular}{|c|c|c|c|c|c|}
\hline \multirow[b]{2}{*}{$\begin{array}{c}\text { Basic } \\
\text { categories }\end{array}$} & \multicolumn{5}{|c|}{ Pattern } \\
\hline & $\begin{array}{c}\text { 1. Active } \\
\text { knowledge } \\
\text { creator }(\mathrm{n}=7)\end{array}$ & $\begin{array}{c}\text { 2. Active } \\
\text { producer }(\mathrm{n}=5)\end{array}$ & $\begin{array}{c}\text { 3. Active } \\
\text { project } \\
\text { manager }(\mathrm{n}=3)\end{array}$ & $\begin{array}{l}\text { 4. Passive } \\
\text { producer } \\
\quad(\mathrm{n}=3)\end{array}$ & $\begin{array}{l}\text { 5. Conformist } \\
(\mathrm{n}=1)\end{array}$ \\
\hline $\begin{array}{l}\text { Approaches } \\
\text { to learning }\end{array}$ & $\begin{array}{c}\text { Deep approach } \\
\text { Surface } \\
\text { approach }\end{array}$ & Surface approach & $\begin{array}{l}\text { Strategic } \\
\text { approach } \\
\text { Surface } \\
\text { approach }\end{array}$ & $\begin{array}{c}\text { Surface } \\
\text { approach }\end{array}$ & $\begin{array}{l}\text { Strategic } \\
\text { approach }\end{array}$ \\
\hline $\begin{array}{l}\text { Action } \\
\text { strategies }\end{array}$ & Transformative & Transformative & Transformative & Adaptive & Adaptive \\
\hline $\begin{array}{l}\text { Locus of } \\
\text { control }\end{array}$ & Internal & Internal & Internal & External & Internal \\
\hline $\begin{array}{l}\text { Perceptions } \\
\text { of the } \\
\text { learning } \\
\text { object }\end{array}$ & $\begin{array}{l}\text { Management of } \\
\text { products } \\
\text { Creation of the } \\
\text { new }\end{array}$ & $\begin{array}{l}\text { Management of } \\
\text { products }\end{array}$ & $\begin{array}{l}\text { Management } \\
\text { of products } \\
\text { Creation of the } \\
\text { new }\end{array}$ & $\begin{array}{l}\text { Management } \\
\text { of products }\end{array}$ & $\begin{array}{l}\text { Management } \\
\text { of products }\end{array}$ \\
\hline
\end{tabular}

\section{Findings}

The results suggested that the natural science doctoral students' learning patterns varied. However, across the learning patterns the students expressed that they had control of their own learning processes. This was shown in learning situations in which the students described having increasingly more ownership over their own learning, being the primary decision maker and conducting their research work in a meaningful manner. The following quotation described the empowering learning experience of an advanced student who had total ownership of his doctoral project for the first time and created a new innovative research idea by himself:

But actually at this point for the first time I got the feeling that I really created something ground-breaking, something new by myself. It was really impressive: I wrote and drew my ideas on paper also at home, and it took several weeks to process the ideas, and I got such a good feeling when after preparing the idea I presented it to others and I got such good feedback about it... For the first time during my doctoral studies I got the feeling that I created something. Producing the doctoral thesis involves making new things, but much of it is directed by the supervisor. And my supervisor has guided the direction of my work. I have had some leeway, but it was really great to get new inspiration from my points of view. (Participant 1)

At the same time, the doctoral students mostly perceived their learning objects as managing different end products that followed each another. The perception became evident in the reports of producing and possessing various tasks and achievements, such as conducting cycles of measurements, obtaining results and publishing articles. The students felt that being able to manage research projects was extremely important, preferably several projects which would produce results that eventually would be reported in the publications forming the entity of the doctoral thesis. Such perceptions were described in the following way by a novice doctoral student (two years or less in doctoral studies):

This first article meant so much: I got my first own article, and it was something concrete that was ready for my doctoral thesis. There are only four articles to be done. (Participant 3 )

However, some students described diverse perceptions of their learning objects. Moreover, differences were seen in the doctoral students' approaches to learning to conduct research and become a researcher as well as in their action strategies in the learning situations. Five learning patterns were identified. In the following sections the patterns are described in detail.

\subsection{Pattern 1: Active Knowledge Creator ( $n=7)$}

Characteristic of the active knowledge creator pattern was that the doctoral students employed both a surface and a deep approach to learning to conduct research and to become a researcher. The surface approach was often seen in learning episodes in which the students focused both on managing and producing their research-related content, such as measurements, analyses and publications. For instance, one advanced student described the uncertainties and challenges related to managing his new research project in the following way: 
When I started this new project for my doctoral thesis, and I had done totally different work before, it was quite hard for me to move from one project to other. During the first months I had no idea how to manage the project; I did not know what to do and how... and no one else had used the instruments that I was supposed to use. I did not progress with that, and simultaneously I was under pressure to get results quickly. (Participant 1 )

The deep approach, on the other hand, became evident in descriptions in which the students developed their own ideas and focused on deepening their understanding of the content. In the following excerpt, a novice doctoral student described the development of his understanding of the field that enabled him to create new research ideas:

Actually now when I have started to see what different kinds of studies are conducted in our research community and what is possible with our resources, and saw what kind of research other international researchers conduct, I gained my own ideas. So I have gained a new, perhaps deeper understanding, and some new ideas have become strengthened. For instance, I have one idea for my next article. (Participant 18)

The students who adopted this pattern felt able to transform and guide their learning. This capability was demonstrated in learning situations where they made attempts to affect the course of their learning by further developing their research project and changing the studying conditions. They described making initiatives both in the content of their doctoral studies and research projects, such as developing them further from their own points of view.

The students who adopted the pattern, however, reported diverse perceptions of the learning objects. The students perceived their learning objects not only as the management of different products, but also as the creation of something new both in terms of knowledge and themselves. Such perceptions were shown in learning episodes in which they described a deepening understanding of their own topic and of the overall domain, problem solving, the development of new ideas and scientific thinking as well as of the formation of their identity as a researcher. Such learning often took place through having dialogue with and working alongside more advanced scientists. These considerations were reported through the following experiences by a student:

I had not written any papers with other researchers, and then we started to do the first one. He had the theme for it and in practice I started to analyse the data with him, and he did almost all the writing and I wrote some sentences. It reminds me of an apprenticeship. From him I learned the value of questioning and asking about everything, and if there is something unclear it should be questioned, not necessarily from others but from oneself, everything needs to double-checked... From him I also learned that it is worth presenting your own ideas. (Participant 8)

The pattern was the most often reported among the participants. The participants included in the pattern represented both genders and were both novice and advanced students.

\subsection{Pattern 2: Active Producer $(n=5)$}

Characteristic of the active producer pattern was that the doctoral students typically employed a surface approach to learning. The students considered their learning to progress linearly and mainly focused on mastering and producing different sub tasks and content. This typically entailed conducting field and laboratory measurements, obtaining proper results and writing articles. The students often described how they had mastered a variety of research-related content and overcome challenges in experiences. A advanced doctoral student described the experiences in the following:

It was quite a straightforward job. I just looked at what things I should mention. And when you know that nobody wants to read long stories, the problem is how to summarize your ideas in a form that someone else gets interested in. In my opinion it was quite easy to do. And of course after you have done one paper, you were able to use it for the others. They are quite similar to each other. By using the existing papers it was easy to do. (Participant 15)

Further investigation showed that similarly to students in the former pattern, the students adopting this pattern reported being able to affect their learning processes. For instance, one novice student described how he had gained the freedom to determine his own doctoral project and to be the decision maker in his process:

I'm still trying to orientate myself, see what everyone is doing, where I can make interesting and productive contributions from my side and what I want to do, what projects are starting soon where I can contribute or want to, and it seems like it's pretty much up to me what I want to do, and I can do it. I'm very free in doing that. (Participant 14)

This pattern was the second most typical and consisted of five male, both novice and advanced doctoral students. 


\subsection{Pattern 3: Active Project Manager ( $n=3)$}

In the active project manager pattern, the doctoral students employed a combination of two different patterns, a strategic and a surface approach to learning. Students who adopted this approach focused on organizing and monitoring their progress with research and study activities, whereas the surface approach was reflected in their managing and producing research tasks such as projects, measurements and articles. In the following excerpt one novice student monitored and reflected on the progress of his doctoral project and its content:

I have one article which is actually ready. And I have some topics for the rest of the articles, of which one I have been conducting a little bit and another I have started. So I think that my doctoral project has advanced well, and I am at quite a good point now. The four-year grant that I have is for writing articles for three years and one year is for writing the thesis. So everything is ok. Of course the speed should be one article in a half year, but in the beginning it progresses more slowly. But I believe that in this time I can manage to conduct the thesis. (Participant 5)

The students who had adopted this pattern were similar to the students in the preceding patterns as they felt able to transform their learning processes. One novice student, for instance, described how he had made plans and goals for his research and how he then carried out the plans under great inspiration:

Then I had some time to think about my doctoral project, what I wanted to do... When I got back to work I changed gears. I did so much work in the fall and I explored new things... And I was so positively surprised how I was able to engage in the work and I was so effective with it. For instance, I wrote the first article in two months from start to finish. (Participant 3)

In addition, the students had fragmented perceptions of their learning objects and considered them to be both end-products and phases that followed each another as well as the creation of new knowledge and the development of academic expertise within the scientific community. One advanced student shared his experience of widening and deepening his theoretical understanding while working alongside a more advanced scientist:

Me and the other doctoral student, we have been working with him, and it has been a good thing to be able to gain an overall understanding of all this... before I had this kind of superficial idea that I should write in the introduction of articles: This topic is important because etc. ... Like I had this idea that I was doing the research, not thinking of the overall picture... Then when he came I gained much more understanding... There is much more to be taken into consideration when exploring this area. (Participant 4)

The pattern included three doctoral students. In this pattern both female and male as well as novice and advanced doctoral students were represented.

\subsection{Pattern 4: Passive Producer ( $n=3)$}

The passive producer pattern entailed the doctoral students employing a surface approach in their learning situations and considering learning objects as concrete outputs. The students focused on managing the content of their research and producing end-products, for instance, measurements and analyses. The students who had adopted this pattern often described their action strategies in the learning situations as mostly adaptive. They also felt that they did not have any control of their learning processes. They did not make their own initiatives or question the current conditions; instead, they typically conformed to their supervisors' or other researchers' decisions and did what was required or asked of them. Examples of adaptive actions, such as those regarding writing an article and conducting measurements, were described in the following way by a novice doctoral student:

They had said to me that there is this other dataset and if I have time I could check them. Then when they came back from the summer holidays it was no longer "if I had time", instead it was "now you have to check them". Then I did the required calculations, and then in the fall when the calculations started to be ready they asked if I would like to write an article on them and I answered no. Then it went $a$ half a year and I was told that I would write the article, so I did it. (Participant 2)

The pattern was seen in three female, novice doctoral students' descriptions.

\subsection{Pattern 5: Conformist $(n=1)$}

In the conformist pattern, one doctoral student applied a strategic approach to learning and perceived learning objects as products and phases. The student also reported having control over learning, including decision making about the research and study content. However, further analysis revealed that the student often adopted adaptive action strategies in the learning episodes. The student, for instance, reported not being able to affect the course of events and therefore followed the decisions made by supervisors and other advanced researchers. In such situations the student reported that he also had control. For instance, this advanced student faced the following situation, in which 
he had to conform to others' decisions while writing a scientific article:

In that publication I conducted the analysis and wrote the article manuscript. I was writing the first version... The idea was that I was the first author. But then suddenly the timetable changed and we were in a hurry. Because of the hurry it turned out that another researcher did the main analysis quickly and finalized the article that I had started. It was kind of like the situation led to that. (Participant 7)

The pattern was the least typical and consisted of one doctoral student.

\section{Discussion}

As stated earlier, to our knowledge, doctoral students' learning patterns have not been previously reported in doctoral education literature. So far, learning patterns have been identified among undergraduate students (Vermunt, 2005; Vermunt \& Vermetten, 2004). This study contributed to the literature on doctoral student learning and provided new insight into the complexity of learning processes among natural science doctoral students by identifying five qualitative different learning patterns: active knowledge creator, active producer, active project manager, passive producer and conformist.

\subsection{Finding in the Light of Previous Research}

The results showed that a surface approach to learning (Entwistle \& McCune, 2004; Lonka et al., 2004) to conduct research and to become a researcher was an aspect of all the patterns. However, two patterns contained fragmented approaches to learning. Students who had adopted the active knowledge creator and active project manager patterns also described a deep approach to learning (Entwistle \& McCune, 2004; Lonka et al., 2004). According to these results, a deep approach to learning among natural science students cannot be taken for granted. One reason for this may lie in the nature of research in the science domain. Often in the natural sciences success in research and the doctorate require managing different research instruments, methods and projects in order to create new knowledge (Delamont \& Atkinson, 2001). Moreover, supervision and guidance typically comprise more hands-on practices (Chiang, 2003; Golde, 2010). Accordingly, student learning often takes place in everyday research practices in the field or laboratory (Cumming, 2009). As a result, students may focus on managing the various contents related to their studies and research projects instead of focusing on gaining a deep understanding of their topics and the overall domain. Further, while doctoral students might develop advanced and structured perceptions of knowledge creation in their field, they may employ more novice learning strategies and perceptions of learning.

The findings showed that the doctoral students who employed fragmented approaches to learning to conduct research and to become a researcher also had adopted incoherent perceptions of their learning objects (Stubb et al., 2012a), both as the management of products and as the creation of the new in terms of knowledge and themselves. One reason for this may be in the nature of scientific research work, which often focuses on the management of end products (e.g. Delamont \& Atkinson, 2001; Cumming, 2009). Another possibility is that the students' perceptions of learning and its objects were changing, and hence, their descriptions of those perceptions were incoherent.

However, in the doctoral students' experiences, the learning object was often the management and production of various end products. This is in line with a previous study suggesting that doctoral students regarded the acquisition of technical skills and management of craft knowledge as more important outcomes of the doctoral process than becoming an expert in their field (Pole, 2000). On the other hand, Stubb et al., (2012b) found that natural science doctoral students mostly considered their research as a journey entailing learning something new in their field or learning the process of becoming part of the research community. This indicates that natural science doctoral students may not necessarily perceive research work only as learning to become a scientist, but they may also consider it to be the production of interdependent research cycles and the results of concrete milestones. Hence, doctoral students' perceptions of learning objects cannot be taken as a fixed entity, at least in the domain of natural sciences.

Moreover, the findings demonstrated that most of the patterns were characterized by transformative action strategies and an internal locus of control in learning situations (Vermunt, 2005). The findings suggest that doctoral students can become self-regulated learners (Pintrich, 2004; Puustinen \& Pulkkinen, 2001) and have active agency (e.g., Pyhältö \& Keskinen, 2012) in their learning processes. This may be supported by the practices of the natural scientific community, such as shared supervision and collaboration (Delamont \& Atkinson, 2001; Cumming, 2009), which support the students' sense of being able to decide and have control over their projects, and the opportunities to affect the course of their process and make their own initiatives. This result contrasts with what Pyhältö and Keskinen (2012) found in their study: a minority of doctoral students perceive that they have active roles within their scholarly communities. However, their results showed that active agency was a buffering factor for reduced 
well-being and attrition: the students who viewed themselves as active agents reported fewer negative emotions and greater interest towards their own work, suffered less from exhaustion and anxiety, and had considered interrupting their studies less often than those who described themselves as passive objects.

In the present study, however, adaptive strategies were identified in two patterns: passive producer and conformist learning. However, the students who adopted these patterns saw their locus of control differently. The students adopting the passive producer pattern did not perceive themselves as active learners since they also perceived the source of control as being external. Accordingly, it seemed that the students had problems in regulating and controlling their own learning processes (Pintrich, 2004; Puustinen \& Pulkkinen, 2001). The students adopting the conformist pattern, on the other hand, felt that they were the source of control in general, but in certain learning situations adapted to other decisions. Hence, the doctoral students' role as active agents is not self-evident and may also depend on the learning situation in question.

In most of the learning patterns both female and male as well as novice and more advanced doctoral students were represented. However, active producer pattern included only male, novice and advanced students. In addition, passive producer pattern involved novice female students. Interpretation of the observations needs to done with caution, because of the size of the sample. More studies in a larger participant group are needed to confirm the patterns identified and to understand the relationships between learning patterns, various outcomes such as study progress, employment after the $\mathrm{PhD}$, gender, and the study phase.

Moreover, further studies are needed to explore the learning patterns among doctoral students from different domains and countries. For instance, longitudinal designs may provide a better understanding of whether students adopt different learning patterns at different phases of the doctoral process. Further studies across different domains may provide insights into whether certain learning pattern trends are more general or are context dependent among doctoral students from various disciplines.

\subsection{Methodological Considerations}

In this study doctoral student learning patterns were explored through semi-structured interviews (Kvale, 2007), which underwent a qualitative content analysis. The strength of the chosen interview design and pattern-oriented analysis was that they enabled a multifaceted and profound investigation of doctoral student learning. However, employing a retrospective approach brings some challenges (Cox \& Hassard, 2007). The participants were interviewed only once, and it is often challenging to recall the doctoral process and sum it up in one session. The participants may have reconstructed the past in the light of present emotions and circumstances (Kvale, 2007). However, the use of the retrospective approach ensured that the participants recalled the most significant past events (Kvale, 2007) related to their learning.

Because of national- and discipline-based differences in doctoral education systems (Golde, 2010; International Postgraduate Student Mirror, 2006) and the small sample size, generalizing the results to other domains and to other countries should be done with caution.

\subsection{Implications for Doctoral Education}

Our findings demonstrated differences in how doctoral students learn. This indicates that learning environments need to be designed to be adjustable for various learning patterns. This does not mean that a specific learning environment is required to adapt to the student's learning pattern; instead, it means creating a constructive friction between the learner and the learning environment (Vermunt \& Verloop, 1999) that requires different support practices and methods that fit each student. Within each learning pattern different practices can enhance the constructive friction between the learner and learning environment. For instance, for students with the active knowledge creation pattern, the learning environment should provide broad opportunities for autonomous learning activities, whereas students with the passive producer pattern need to be supported gradually towards active and self-regulated learning (e.g., Pintrich, 2004; Zimmerman, 2008). Becoming self-regulated learner can be supported by helping the students setting goals for their doctoral studies, and choosing strategies for striving for the goals and for evaluating the progress, for instance by using personal doctoral study plans with regular updating.

Special attention should be given to how to support those students who employ adaptive strategies but do not see themselves as the source of control in their learning to conduct research and become a researcher. If a doctoral student perceives that he cannot influence or control his learning process, his interest in the doctoral project may decrease, and he may lose all motivation to conduct the doctoral thesis. At its worst, such an experience may lead to cynicism towards one's own research and science in general (Vekkaila et al., 2013b, 2014) and even to abandoning doctoral studies (Stubb, Pyhältö, \& Lonka, 2011). Such students are likely to need guidance to develop active agency in terms of the learning environment and research work (Pyhältö \& Keskinen, 2012). 
Intentional learning activities can be supported in environments which enable doctoral students to share their knowledge and expertise with others, take more responsibility for and ownership of their learning, and perceive themselves as a contributing member of their community (Dunlap, 2006; McAlpine \& Amundsen, 2009). This requires open discussions between doctoral students, their supervisors and other members of the research community on how to facilitate students to gradually take more ownership of their research and becoming accountable members of their researcher communities. Solutions could involve active and collaborative learning techniques and providing interesting academic challenges for students (Bresó, Schaufeli, \& Salanova, 2011; Overall, Deane, \& Peterson, 2011). Actions that supervisors could use to promote intentional learning among doctoral students might be, for instance, supporting and encouraging students to take increasingly more responsibility for planning, monitoring and evaluating their study courses and academic papers such as co-authored articles, and designing research projects. Learning environments that are sensitive to doctoral students' different ways of learning are also likely to improve their persistence in doctoral studies (e.g., Terrell, 2002). At best, by designing practices in congruence with doctoral students' ways of learning, scholarly communities can provide environments in which various doctoral students are able to flourish.

\section{References}

Anderson, S., \& Anderson, B. (2012). Preparation and socialization of the education professoriate: Narratives of doctoral student-instructors. International Journal of Teaching and Learning in Higher Education, 24(2), 239-251.

Retrieved

from http://docplayer.net/12766860-Preparation-and-socialization-of-the-education-professoriate-narratives-of-doctor al-student-instructors.html

Anderson, B., Cutright, M., \& Anderson, S. (2013). Academic involvement in doctoral education: Predictive value of faculty mentorship and intellectual community on doctoral education outcomes. International Journal of Doctoral Studies, 8, 195-201. Retrieved from http://ijds.org/Volume8/IJDSv8p195-201Anderson0405.pdf

Austin A. E. (2002). Preparing the next generation of faculty: Graduate school as socialization to the academic career. The Journal of Higher Education, 73(1), 94-122. http://dx.doi.org/10.1353/jhe.2002.0001

Biggs, J. (1978). Individual and group differences in study processes. The British Journal of Educational Psychology, 48(3), 266-279. http://dx.doi.org/ 10.1111/j.2044-8279.1978.tb03013.x

Bresó, E., Schaufeli, W. B., \& Salanova, M. (2011). Can a self-efficacy -based intervention decrease burnout, increase engagement, and enhance performance? A quasi-experimental study. Higher Education, 61(4), 339-355. http://dx.doi.org/10.1007/s10734-010-9334-6

Brew, A., Boud, D., \& Namgung. S. U. (2011). Influences on the formation of academics: The role of the doctorate and structured development opportunities. Studies in Continuing Education, 33(1), 51-66. http://dx.doi.org/10.1080/0158037X.2010.515575

Chiang, K. (2003). Learning experiences of doctoral students in UK universities. International Journal of Sociology and Social Policy, 23(1/2), 4-32. http://dx.doi.org/10.1108/01443330310790444

Coffey, A., \& Atkinson, P. (1996). Making sense of qualitative data. Complementary research strategies. Thousand Oaks, CA: Sage.

Cox, J. W., \& Hassard, J. (2007). Ties to the past in organization research: A comparative analysis of retrospective methods. Organization, 14(4), 475-497. http://dx.doi.org/10.1177/1350508407078049

Cumming, J. (2009). The doctoral experience in science: Challenging the current orthodoxy. British Educational Research Journal, 35(6), 877-890. http://dx.doi.org/10.1080/01411920902834191

Delamont, S., \& Atkinson, P. (2001). Doctoring uncertainty: Mastering craft knowledge. Social Studies of Science, 31(1), 87-107. http://dx.doi.org/10.1177/030631201031001005

Dunlap, J. C. (2006). The effect of a problem-centered, enculturating experience on doctoral students' self-efficacy. Interdisciplinary Journal of Problem-based Learning, 1(2), 19-48. http://dx.doi.org/10.7771/1541-5015.1025

Entwistle, N. J., \& McCune, V. (2004). The conceptual bases of study strategy inventories. Educational Psychology Review, 16(4), 325-345. http://dx.doi.org/10.1007/s10648-004-0003-0

Entwistle, N. J., \& Peterson, E. R. (2004). Conceptions of learning and knowledge in higher education: Relationships with study behaviour and influences of learning environments. International Journal of Educational Research, 41, 407-428. http://dx.doi.org/10.1016/j.ijer.2005.08.009

Gardner, S. K. (2007). "I heard it through the grapevine": Doctoral student socialization in chemistry and history. 
Higher Education, 54(5), 723-740. http://dx.doi.org/10.1007/s10734-006-9020-x

Gardner, S. K., \& Barnes, B. J. (2007). Graduate student involvement: Socialization for the professional role. Journal of College Student Development, 48(4), 1-19. http://dx.doi.org/10.1353/csd.2007.0036

Golde, C. M. (2010). Entering different worlds. Socialization into disciplinary communities. In S.K. Gardner \& P. Mendoza (Eds.), On becoming a scholar. Socialization and development in doctoral education (pp. 79-95). Virginia, USA: Stylus Publishing, LLC.

Haig, B. D. (2005). An abductive theory of scientific method. Psychological Methods, 10(4), 371-388. http://dx.doi.org/10.1037/1082-989X.10.4.371

Harry, B., Sturges, K. M., \& Klingner, J. K. (2005). Mapping the process: An exemplar of process and challenge in grounded theory analysis. Educational Researcher, 3-13. http://dx.doi.org/10.3102/0013189X034002003

International Postgraduate Student Mirror. (2006). Catalonia, Finland, Ireland and Sweden. Högskoleverket, Swedish National Agency for Higher Education, 29R. Retrieved from http://www.ub.edu/depdibuix/ir/0629R-shv_se-catalonia.pdf

Kvale, S. (2007). Doing interviews. London: Sage Publications.

Lahenius, K., \& Martinsuo, M. (2011). Different types of doctoral study processes. Scandinavian Journal of Educational Research, 55(6), 609-623. http://dx.doi.org/10.1080/00313831.2011.555924

Lonka, K., Olkinuora, E., \& Mäkinen, J. (2004). Aspects and prospects of measuring studying and learning in higher education. Educational Psychology Review, 16(4), 301-323. http://dx.doi.org/10.1007/s10648-004-0002-1

Lovitts, B. E. (2005). Being a good course-taker is not enough: A theoretical perspective on the transition to independent research. Studies in Higher Education, 30(2), 137-154. http://dx.doi.org/10.1080/03075070500043093

McAlpine, L., \& Amundsen, C. (2009). Identity and agency: Pleasures and collegiality among the challenges of the doctoral journey. Studies in Continuing Education, 31(2), 109-125. http://dx.doi.org/10.1080/01580370902927378

McAlpine, L., Jazvac-Martek, M., \& Hopwood, N. (2009). Doctoral student experience in education: Activities and difficulties influencing identity development. International Journal for Researcher Development, 1(1), 97-109. http://dx.doi.org/10.1108/1759751X201100007

McAlpine, L., \& Norton, J. (2006). Reframing our approach to doctoral programs: An integrative framework for action and research. Higher Education Research \& Development, 25(1), 3-17. http://dx.doi.org/10.1080/07294360500453012

Meyer, J. H. F., Shanahan, M. P., \& Laugksch, R. C. (2005). Students' conceptions of research I: A qualitative and quantitative analysis. Scandinavian Journal of Educational Research, 49(3), 225-244. http://dx.doi.org/10.1080/00313830500109535

Miles, M. B., \& Huberman, A. M. (1994). Qualitative data analysis. (2nd ed.). Thousand Oaks, CA: Sage publications.

Mills, J., Bonner, A., \& Francis, K. (2006). The development of constructivist grounded theory. International Journal of Qualitative Methods, 5(1), 25-35. Retrieved from http://www.ualberta.ca/ iiqm/backissues/5_1/pdf/mills.pdf

Overall, N. C., Deane, K. L., \& Peterson, E. R. (2011). Promoting doctoral students' research self-efficacy: Combining academic guidance with autonomy support. Higher Education Research \& Development, 30(6), 791-805. http://dx.doi.org/10.1080/07294360.2010.535508

Patton, M. Q. (1990). Qualitative research and evaluation methods. (2nd ed.). Newbury Park, CA: Sage Publications.

Pintrich, P. R. (2004). A conceptual framework for assessing motivation and self-regulated learning in college students. Educational Psychology Review, 16(4), 385-407. http://dx.doi.org/10.1007/s10648-004-0006-x

Pole, C. (2000). Technicians and scholars in pursuit of the PhD: Some reflections on doctoral study. Research Papers in Education, 15(1), 95-111. http://dx.doi.org/10.1080/026715200362961

Puustinen, M., \& Pulkkinen, L. (2001). Models of self-regulated learning: a review. Scandinavian Journal of Educational Research, 45(3), 269-286. http://dx.doi.org/10.1080/00313830120074206 
Pyhältö, K., Nummenmaa, A. R., Soini, T., Stubb, J., \& Lonka, K. (2012). Research on scholarly communities and development of scholarly identity in Finnish doctoral education. In S. Ahola \& D. M. Hoffman (Eds.), Higher education research in Finland. Emerging structures and contemporary issues (pp. 337-357). Jyväskylä: Jyväskylä University Press.

Pyhältö, K., \& Keskinen, J. (2012). Doctoral students' sense of relational agency in their scholarly communities. International Journal of Higher Education, 1(2), 136-149. http://dx.doi.org/10.5430/ijhe.v1n2p136

Pyhältö, K., Stubb, J., \& Lonka, K. (2009). Developing scholarly communities as learning environments for doctoral students. International Journal for Academic Development, 14(3), 221-232. http://dx.doi.org/10.1080/13601440903106551

Pyhältö, K., Stubb, J., \& Tuomainen, J. (2011). International evaluation of research and doctoral education at the University of Helsinki - To the top and out to society. Summary report on doctoral students' and principal investigators' doctoral training experiences. Retrieved from http://wiki.helsinki.fi/display/evaluation2011/Survey+on+doctoral+training

Saunders, C. (2009). Developing researchers in the arts and humanities: Lessons from a pilot programme to develop discipline-specific research skills. International Journal for Researcher Development, 1(1), 45-69. http://dx.doi.org/10.1108/1759751X201100004

Stubb, J., Pyhältö, K., \& Lonka, K. (2011). Balancing between inspiration and exhaustion: PhD students' experienced socio-psychological well-being. Studies in Continuing Education, 33(1), 33-50. http://dx.doi.org/10.1080/0158037X.2010.515572

Stubb, J., Pyhältö, K., \& Lonka, K. (2012a). The experienced meaning of working with a PhD thesis. Scandinavian Journal of Educational Research, 56(4), 439-456. http://dx.doi.org/10.1080/00313831.2011.599422

Stubb, J., Pyhältö, K., \& Lonka, K. (2012b). Conceptions of research: The doctoral student experience in three domains. Studies in Higher Education 39(2). 251-264. http://dx.doi.org/10.1080/03075079.2011.651449

Sweitzer, V. (2009). Towards a theory of doctoral student professional identity development: A developmental networks approach. The Journal of Higher Education, 80(1), 1-33. http://dx.doi.org/10.1353/jhe.0.0034

Terrell, S. R. (2002). The effect of learning style on doctoral course completion in a Web-based learning environment. Internet and Higher Education, 5, 345-352. http://dx.doi.org/10.1016/S1096-7516(02)00128-8

Tripp, D. (1994). Teachers' lives, critical incidents, and professional practice. Qualitative Studies in Education, 7(1), 65-76. http://dx.doi.org/10.1080/0951839940070105

Vekkaila, J., Pyhältö, K., Hakkarainen, K., Keskinen, J., \& Lonka, K. (2012). Doctoral students' key learning experiences in the natural sciences. International Journal for Researcher Development, 3(2), 154-183. http://dx.doi.org/10.1108/17597511311316991

Vekkaila, J., Pyhältö, K., \& Lonka, K. (2013a). Focusing on doctoral students' experiences of engagement in thesis work. Frontline Learning Research, 1(2), 10-32. http://dx.doi.org/10.14786/flr.v1i2.43

Vekkaila, J., Pyhältö, K., \& Lonka, K. (2013b). Experiences of disengagement - A study of doctoral students in the behavioral sciences. International Journal of Doctoral Studies, 8, 61-81. Retrieved from http://ijds.org/Volume8/IJDSv8p061-081Vekkaila0402.pdf

Vekkaila, J., Pyhältö, K., \& Lonka, K. (2014). Engaging and disengaging doctoral experiences in the behavioural sciences. International Journal for Researcher Development, 5(1), 33-55. http://dx.doi.org/10.1108/IJRD-09-2013-0015

Vermunt, J. D. (2005). Relations between student learning patterns and personal and contextual factors and academic performance. Higher Education, 49, 205-234. http://dx.doi.org/10.1007/s10734-004-6664-2

Vermunt, J. D., \& Verloop, N. (1999). Congruence and friction between learning and teaching. Learning and Instruction, 9(3), 257-280. http://dx.doi.org/10.1016/S0959-4752(98)00028-0

Vermunt, J. D., \& Vermetten, Y. J. (2004). Patterns in student learning: Relationships between learning strategies, conceptions of learning, and learning orientations. Educational Psychology Review, 16(4), 359-384. http://dx.doi.org/10.1007/s10648-004-0005-y

Wisker, G., Robinson, G., Trafford, V., Creighton, E., \& Warnes, M. (2003). Recognising and overcoming dissonance in postgraduate student research. Studies in Higher Education, 28(1), 91-105. http://dx.doi.org/10.1080/03075070309304 
White, J., \& Nonnamaker, J. (2008). Belonging and mattering. How science doctoral students experience community. NASPA Journal, 45(3), 350-372. http://dx.doi.org/10.2202/1949-6605.1860

Zimmerman, B. J. (2008). Investigating self-regulation and motivation: Historical background, methodological developments, and future prospects. American Educational Research Journal, 45(1), 166-183. http://dx.doi.org/10.3102/0002831207312909

\section{Appendix}

Critical events and turning points during the doctoral process interview

What is your field /discipline or subject?

How many years have you been a doctoral student?

How old are you?

Are you writing a monograph or a series of articles?

Are you doing your doctoral studies and research full-time or part-time?

What is the topic of your doctoral thesis/What is your research about?

What is the phase of your doctoral studies?

Instructions to the participant:

In this interview we will examine your doctoral process and its different critical events or turning points. Please visualise your doctoral research and study process. This visualisation can be some kind of a line, a map, or a spiral and so on, in terms of how you see it. This visualisation will work as a support for your memory. It is thought that with the help of a visualisation one can reflect on critical and significant events and points that cannot be so easily verbalised. Now think about the whole process, the whole path of your doctoral research and studies. How would it look on this paper? Visualise it on the paper in the way you see it. Think about what kinds of key events or turning points your process includes? Mark those clearly on the visualisation, and mark the year there, too. Let's go event by event, let's see what happened in each event and which other persons or groups have had some role in those events. Choose one event where you would like to start.

- Tell me what happened in that event? Tell me everything you remember related to this event.

Elaborative questions (when needed):

- Where did this happen? When this did happen? Mark the year.

- Why do you think this happened? What do you think are the reasons behind this?

- What did you think in this situation?

- What did you do?

- What happened then? Did this have some effect on you? If it did, how did it affect you?

- Were there some persons or groups who had a role in the event, had some effect on your process?

- Tell me more about this person/these persons. Who are they? What kind of effect did they have on this event? What were their roles?

- Background information of the other persons (age, profession, and workplace), how the participant and the person met, and connections between the identified persons/groups.

- Do you feel like you have forgotten something or is there still anything you would like to add?

- Is there some person or persons who have not come out in this interview but who have had some role in your doctoral research or who had some effect on your research life? Who is he/she? What role/effect did he/she have, and can they be attached to some event or phase?

- How is your research funded?

- Are there any questions that you would have wished to be asked about? If yes, would you like to answer them?

- Is there something you would like to ask about this interview or the research project? 